\title{
Class Mobility and Political Preferences: Individual and Contextual Effects ${ }^{1}$
}

\author{
Nan Dirk De Graaf and Paul Nieuwbeerta \\ University of Nijmegen \\ Anthony Heath \\ Nuffield College
}

The authors test several hypotheses about the impact of intergenerational class mobility on political party preferences. Tests using cross-national data sets representing Britain, the Netherlands, Germany, and the United States over the period 1964-90 suggest a process of acculturation to the class of destination. The authors hypothesized that a class with a high degree of demographic identity influences newcomers more than a class with low demographic identity does and that, the more left-wing inflow there is into a class, the more likely the immobile members are to have left-wing political preferences. The data did not confirm these hypotheses. A macro analysis does, however, show that the level of class voting is weakened by a compositional mobility effect.

\section{INTRODUCTION}

It is generally true that a member of the working class is more likely to vote for a left-wing political party than is a member of the middle class, although the extent of such class voting varies greatly between countries. In Britain, for example, it is relatively strong, whereas in America, particularly in recent years, it has been rather weak. Moreover, even in countries where class voting is relatively strong, the proportion voting for the "natural" party of their class rarely exceeds 60\% (Heath et al. 1991, pp. 68-69).

${ }^{1}$ This research was supported by the Royal Netherlands' Academy of Arts and Sciences, the Netherlands Organization for Scientific Research (grant no. 500-279-001), and the Economic and Social Research Council (award Y303253001). We especially wish to thank Wout Ultee and three $A J S$ reviewers for their detailed comments, Harry Ganzeboom, Herbert Kritzer, Mildred Schwartz, and Marco Steenbergen for their suggestions, and Jeroen Weesie and David Firth for their statistical advice. Direct correspondence to Nan Dirk De Graaf, University of Nijmegen, Department of Sociology, P.O. Box 9104, 6500 HE Nijmegen, Netherlands. E-mail: U211313@vm.uci. kun.nl

(c) 1995 by The University of Chicago. All rights reserved.

0002-9602/95/10004-0005\$01.50 
To understand fully the relationship between class position and political preference one has to remember that socioeconomic classes in the advanced industrial societies are far from homogeneous and static. In all Western countries, although not always to the same extent, people move up and down the social ladder with respect to their parents. Processes of social mobility, therefore, may help to explain "class-deviant" behavior within a country (Abramson 1972).

A number of empirical studies have investigated the impact of social mobility on voting behavior (Lipset and Zetterberg 1956; Lipset and Bendix 1959; Barber 1970; Abramson 1972; Kelley 1992; Turner 1992; Weakliem 1992). Most of these adopt a microsociological perspective and focus on the impact of an individual's mobility experience on his or her voting behavior; almost invariably they have shown that the political behavior of the mobile is intermediate between that of the stable members of their origin and destination classes. However, there is also an older tradition of macrosociology that looks at the emergent properties of social formations (Durkheim 1897; Blau 1964; Blau and Schwartz 1984). That is to say, rates of social mobility may affect the degree of cohesion and solidarity within a particular class, and this in turn may influence the overall level of class voting.

Mobility processes may therefore have important consequences for levels of class polarization, and they may help to explain both over-time and cross-national variations in class voting (De Graaf and Ultee 1990; Heath et al. 1991; Nieuwbeerta 1995). In particular higher absolute rates of mobility may be expected to reduce class polarization by increasing the proportion of mobile voters with intermediate propensities to support the left (which we term compositional effects) and also by weakening class solidarity and pulling even the nonmobile voters toward the center (which we term the contextual effects on the immobile).

In this article we first discuss two main theories of the relation between class and political preference. On the basis of these theories we suggest some micro hypotheses about the effects of an individual's mobility experiences on political preferences. Next, we consider macro hypotheses about the compositional and contextual effects of mobility rates. In the next four sections, we describe our data, discuss our models, and present the results of testing our micro and macro hypotheses. In these tests we restrict ourselves to the analysis of men. De Graaf and Heath (1992) have shown that working women should not be assigned to social classes solely on the basis of their husband's occupation or solely on the basis of their own occupation. For women, more complex models are required that take account of the interactions between husbands' and wives' occupations. We therefore believe that women's mobility deserves a separate 
treatment in its own right, and we hope to present this in a separate publication.

\section{MICRO EFFECTS OF INTERGENERATIONAL MOBILITY ON POLITICAL PREFERENCE}

In order to obtain a better insight into the consequences of intergenerational class mobility for political preference, we begin with two main theories of individual voting behavior. The first is the economic theory of political behavior (Downs 1957), sometimes also known as the "instrumental" theory. The basic idea here is that voting behavior is rational and self-interested: People vote for the party whose policies will bring them the greatest utility in the future. Class voting can then be explained on the grounds that people in lower social classes have an interest in redistributive policies, which are typically espoused by left-wing parties, while the members of higher social classes have an interest in opposing such policies (Lipset et al. 1954; Converse 1958).

The second theory, labeled by Heath, Jowell, and Curtice (1985, p. 9) as the "expressive" theory, perceives voting as a social act rather than an instrumental act. The assumption of this theory is that political identities are developed through interaction with others. Voting behavior is thus an expression of a political identity and will in turn reflect the norms and values of one's normative reference group. With this theory, too, it is rather straightforward to explain the relationship between class position and political preference. In many cases a person associates with other people occupying the same class position. They are raised by them, live in the same area, attend the same school, work together as colleagues, and thus learn the traditional culture of their shared class. Consequently, they will vote as their class members traditionally vote.

Although these two theories are quite different with respect to their initial assumptions, in predicting the relation between class and political preference, they are not contradictory but complementary (Heath et al. 1985, p. 9). To phrase the complementary character of both theories: People can vote for the same party both because of their mutual interest and because they are influenced by each other. We might add that associating with others from the same class may make people more conscious of their common interests and of the party that serves their interests best.

However, the two theories do have rather different implications for the relationship between social mobility and political preference. In its simplest version, the instrumental theory predicts that the political preferences of the mobile will be identical to those of their class of destination, although, given the evidence on countermobility (Girod 1971; Goldthorpe 
1980), one might expect there to be some modest influence from social origins too. That is, some people might expect their current class positions to be temporary and might anticipate returning to their class of origin; hence they might define their long-run interests as those of their class of origin. On the basis of the instrumental theory, therefore, one would predict that the political preferences of the mobile will be closer to the typical political preferences of their class of destination than to that of their class of origin. This is what De Graaf and Ultee (1990) called the "economic hypothesis," and it is our first hypothesis at the micro level.

The expressive theory, on the other hand, predicts a larger role for social origins, since the culture of one's origin class is likely to be particularly important in early political socialization. However, the older someone is, the more distant is their primary socialization in their family and class of origin and, conversely, older respondents will in general have had a longer period in their class of destination (most intergenerational class mobility between the broad classes that we have identified takes place at a relatively early stage of the career and little occurs after the age of 35; Goldthorpe 1980, pp. 69-71). Our "acculturation hypothesis" therefore states that the older one is the more the impact of the class of origin diminishes relative to that of the class of destination. This hypothesis is in line with Blau's "pattern of acculturation" (1956) and follows directly from the expressive theory. It is unlikely that the mobile will have no social contacts with their class of origin. Social networks change slowly, and it may take time for the mobile to integrate socially into their class of destination and to lose their old social identity.

A further issue that has often been raised is whether there is an asymmetry in the patterns of adaptation of upwardly and downwardly mobile people. Lipset (1960), for example, assumed that upwardly mobile people adapt more quickly to their destination class than do those who are downwardly mobile. His underlying idea was that people in general prefer to adopt the more prestigious identity and, thereby, to maximize their status. We term this the status maximization hypothesis. That is, people may prefer to take as their normative reference group whichever is the higher of their classes of origin and destination. The "status maximization hypothesis," then, is that downwardly mobile persons orient themselves more to their origin class, while upwardly mobile persons will orient themselves more to their destination class. ${ }^{2}$ Similar statements

${ }^{2}$ We would like to emphasize that this hypothesis is not just the prediction that political preference will be a weighted average between origin and destination. The literature on social mobility and political preference often suggests that, due to the "shock of mobility" (comparable to the often assumed status inconsistency effect), mobility has an extra independent effect. Turner (1992) labels this the "effect of 
have been made by Parkin (1971, pp. 51, 54), Knoke (1973), and Thorburn (1979), although subsequent empirical research has generally failed to confirm this hypothesis (Abramson 1972; De Graaf and Ultee 1990; Nieuwbeerta and De Graaf 1993; Clifford and Heath 1993).

\section{MACRO EFFECTS OF INTERGENERATIONAL MOBILITY ON POLITICAL PREFERENCE}

The theoretical questions raised at the macrolevel include some of the central ones of stratification research, for example, questions about the potential for class-based collective action. The classic statement of this was Marx's explanation for the absence of social classes in America. Thus in a well-known passage, Marx (1926, p. 33) argued that in America "classes are not yet fixed, but in continual flux, with a persistent interchange of their elements." In other words, high rates of social mobility undermine class formation. Sorokin $(1957$, p. 538) argued that social mobility facilitates atomization and diffusion of solidarity and antagonisms. Similar ideas have been widespread in the many accounts of the decline of class in contemporary societies: Increasing rates of social mobility have, it is claimed, tended to weaken the cohesion of the classes and have been one of the factors in class dealignment (Clark and Lipset 1991).

Goldthorpe (1980) has followed up these broad claims with more specific hypotheses in his work on class formation. He distinguishes between the demographic identity of a class (defined by its patterns of inter- and intragenerational mobility) and the sociopolitical orientations that demography may promote. The implications of these demographic considerations for normative patterns seem clear enough. As Goldthorpe suggests (1980, p. 268), "the fact that over recent decades [the service class] has recruited from very diverse sources must have seriously reduced its sociocultural distinctiveness; to some extent mobile men carry with them the normative and relational patterns of their class origins into their class of destination, and thereby increase its internal heterogeneity. However, the case of the working class is clearly a different one. It is from its recruitment patterns - that is from the homogeneity of the social origins of its members - that its demographic identity primarily derives; and in turn, one may then suppose, its sociocultural homogeneity is in this way also favoured."

There are two rather different ways in which one could interpret these ideas and then put them to the test-the compositional and the contex-

mobility per se." We feel that our status maximization hypothesis is a more specific hypothesis on mobility effects. 
tual. First, within an individualistic perspective, one might claim that the sociocultural orientations of a class are simply the summation of those of the individuals that make up the class. We term this the "compositional interpretation." As the service class expands and includes more people from non-service-class origins, so its demographic homogeneity will decline. If these newcomers retain to some extent the political orientations of their class origins, and if these orientations are different from those of the stable members of the class of destination, it follows arithmetically that the political complexion of the class as a whole must change. However, it is important to acknowledge that it is not just the amount of inflow mobility that may be important. The impact of inflow mobility may also depend on the political preferences of the newcomers. For example, we know that the political preferences of the service class are not very different from the preferences of the routine nonmanual class whereas the manual class differs substantially in this respect. This suggests that inflow into the service class from the routine nonmanual class may have less impact politically than the same amount of inflow from the manual class. The compositional effects of mobility depend, therefore, both on the amount and on the political character of that mobility.

However, we might also wish to argue, on Durkheimian lines, that the culture of a class is more than the sum of individual orientations. In other words, class culture may be an emergent property of the class, deriving from the interaction between the individuals who currently make up the class. Thus a class with a high degree of demographic identity may have a stronger normative subculture than one with a lower degree of demographic identity, and this in turn may exert a stronger pressure on newcomers to the class. The process of acculturation to the norms and values of the class of destination may be faster and more complete if the class has a high degree of demographic identity. We term this the "contextual interpretation." Weakliem (1992, p. 155) neatly summarized this argument as follows: "Effects of origin and destination class may vary according to the nature of socialization of different classes. Some social groups (classes) may have a strong culture which places a definite stamp on newcomers. . . . Other groups (classes) may have little sense of common identity and consequently little impact on the views of new arrivals." Our "contextual hypothesis for the mobile," therefore, states that a class with a low level of inflow mobility (and therefore a high level of demographic identity) will have a greater impact on newcomers than will a class with a higher rate of inflow mobility. ${ }^{3}$

\footnotetext{
${ }^{3}$ A similar hypothesis was postulated by Ultee and De Graaf (1991) to explain culture consumption.
} 
So far we have considered only hypotheses about the behavior of intergenerationally mobile individuals. Although most of the literature concentrates on the mobile, this is only half the story. As Blau and Schwartz (1984, p. 55) have pointed out, immobile people too can be affected by mobility processes: "Mobility has cumulative effects on intergroup processes. First, since mobile persons have more intergroup associates than nonmobile persons, many mobiles raise the group's average [our compositional effect]. Second, they sometimes introduce their friends from the two groups, initiating intergroup relations between these. Third, the consequent high rates of intergroup relations in communities with many mobiles indicate weaker ingroup pressures [our contextual hypothesis for the mobile]. Finally, the relatively frequent intergroup relations lessen ingroup salience, even among those who themselves are not involved in intergroup associations, further facilitating contacts in the future. The inference is that extensive mobility promotes intergroup relations of a population's nonmobile as well as its mobile members."

Thus if there is a large inflow into a class, the chances that an immobile class member will be influenced by the newcomers may be relatively high (see also Lipset 1960). The impact of the newcomers may be expected to depend on the political orientations that they bring with them, and so our "contextual hypothesis for the immobile" is that the more left-wing mobility into a class there is, the more likely are the immobile members of that class to have a left-wing political preference.

\section{DATA}

While the micro hypotheses can be tested on a single data set from one country, it is of some interest to test whether they hold true for other countries or at other times. In the case of the macro hypotheses, moreover, it is essential to increase the number of data sets. In our contextual hypotheses the unit of analysis becomes the class and, with the six-class schema that we use in this article, each data set thus yields six observations. In order to obtain an adequate number of observations we therefore employ a total of 55 data sets from four countries: Britain, Germany, the Netherlands, and the United States. The data file for the Netherlands contains 13 Dutch representative surveys over the period 1970-90. The U.S. file consists of 17 GSS data sets over the period 1972-90. The British file consists of seven National Election Studies covering the 1964-87 period. For Germany the file is built upon 19 representative surveys covering the period 1969-90. The surveys used are listed in the data references list. The merged data files contain comparable information on respondent's class, father's class, and respondent's poli- 
tical preference. Additional comparable relevant variables that are included in our data set are age, religion, ethnicity, and year of interview.

From the data, we have selected male respondents: 11,949 for the United States, 8,349 for Britain, 10,489 for the Netherlands, and 19,216 for Germany. From these respondents, we selected those 18 years old or older who had a valid score on all relevant variables. These restrictions reduce the number of cases to 9,372 for the United States, 6,168 for Britain, 7,086 for the Netherlands, and 10,596 for Germany.

\section{Political Preference}

Political preference, our dependent variable, is measured in somewhat different ways in the different surveys. In all cases in the British and U.S. surveys (and in many of the German and Dutch surveys) respondents were asked to name the political party they voted for in the most recent national election. In the other German and Dutch surveys the questions tapped vote intention. ${ }^{4}$ In this article we use the phrase "political preference" for all these measures. The difference between these measures of political preference is a limitation that must be borne in mind. However, experiments with the different treatments of the dependent variable showed that our conclusions are not sensitive to these differences. In order to achieve a measure of international comparability we have followed Bartolini and Mair's (1990) and Franklin, Mackie, and Valen's (1992) procedures and dichotomized political preference into a preference for left-wing parties (coded "1") versus other parties (coded " 0 "). ${ }^{5}$

\footnotetext{
${ }^{4}$ Surveys (see data references list) asked about voting preferences in the following ways: which party the respondent voted for in the last national elections (Barnes and Kaase 1976; Werkgroep Nationaal Kiezersonderzoek 1977; Van der Eijk, Niemoeller, and Eggen 1981; Van der Eijk et al. 1982; Van der Eijk, Irwin, and Niemoeller 1986; ZUMA 1980; International Social Science Program 1987; Butler and Stokes 1963-66, 1970; Crewe, Saerlvik, and Alt 1974; Crewe, Saerlvik, and Robertson 1979; Heath et al. 1983; Heath et al. 1989; Davis and Smith 1991); which party the respondent would vote for if national elections were held today/tomorrow (Heunks et al. 1973; Verba, Nie, and Kim 1971; Allerbeck et al. 1980; Felling, Peters, and Schreuder 1985; Eisinga et al. 1990; Barnes and Kaase 1976; ZUMA 1988, 1990); which national political party the respondent prefers (Hermkens and Van Wijngaarden 1976; CBS 1977; Arts et al. 1989); and which party the respondent expected to vote for in the upcoming national elections (Kaase and Schleth 1969; Klingemann and Pappi 1969; Allerbeck et al. 1980). Exact wording for the questions used in the surveys can be found in the original codebooks.

${ }^{5}$ The following parties are coded as left wing: Germany-Social Democrats, Communist Party, Independent Social Democrats, and Action for Democratic Progress; Netherlands-Labour Party, Social Democratic League, Socialist Party, Revolutionary
} 
TABLE 1

Social Class Schema

\begin{tabular}{|c|c|c|c|}
\hline Number & Title & Description & $\begin{array}{c}\text { EGP } \\
\text { Categories* }\end{array}$ \\
\hline $1 \ldots \ldots \ldots$ & Service class & $\begin{array}{l}\text { Professionals, administrators, } \\
\text { and managers; higher-grade } \\
\text { technicians; supervisors of } \\
\text { nonmanual workers }\end{array}$ & 1,2 \\
\hline $2 \ldots \ldots \ldots$ & Routine nonmanual workers & $\begin{array}{l}\text { Routine nonmanual employees } \\
\text { in administration and com- } \\
\text { merce; sales personnel; } \\
\text { other rank-and-file service } \\
\text { workers }\end{array}$ & 3 \\
\hline $3 \ldots \ldots \ldots$ & Petty bourgeois & $\begin{array}{l}\text { Small proprietors and arti- } \\
\text { sans, with and without em- } \\
\text { ployees }\end{array}$ & $4 a, 4 b$ \\
\hline $4 \ldots \ldots \ldots$ & Farmers & $\begin{array}{l}\text { Farmers, smallholders, and. } \\
\text { other self-employed workers } \\
\text { in primary production }\end{array}$ & $4 c$ \\
\hline $5 \ldots \ldots \ldots$ & $\begin{array}{l}\text { Skilled and unskilled manual } \\
\text { workers }\end{array}$ & $\begin{array}{l}\text { Lower-grade technicians; su- } \\
\text { pervisors of manual work- } \\
\text { ers; skilled manual workers; } \\
\text { semi- and unskilled, nonag- } \\
\text { ricultural manual workers }\end{array}$ & $5,6,7 a$ \\
\hline $6 \ldots \ldots \ldots$ & Agricultural laborers & $\begin{array}{l}\text { Agricultural and other work- } \\
\text { ers in primary production }\end{array}$ & $7 b$ \\
\hline
\end{tabular}

*Numbers indicate the categories of the EGP schema (Erikson et al. 1979; Erikson and Goldthorpe 1992) that we have combined to define our categories.

\section{Social Class}

The social class variable is coded according to a collapsed version of Erikson, Goldthorpe, and Portocarero's (EGP schema; see Erikson, Goldthorpe, and Portocarero 1979; Erikson and Goldthorpe 1992). We use this schema because it has proved to be useful in comparative intergenerational mobility research (Ganzeboom, Luijkx, and Treiman 1989) and in analyses of the consequences of social mobility for political preference (Nieuwbeerta and De Graaf 1993; Clifford and Heath 1993). Because of limitations in the data (e.g., because in some surveys detailed information on self-employment and supervisory status is lacking), we are not able to use more extended versions of the EGP schema.

The class schema that we shall use is shown in table 1 . Respondents

Socialist Party, Communist Party, Pacifist Socialist Party, and Democratic Socialist '70; Great Britain - Labour Party; United States-Democratic Party. 
were coded into classes based on their occupation, self-employment, and supervisory status. ${ }^{6}$ We should note that the schema is not intended to be strictly hierarchical and that it has a nonlinear relationship with vote.

\section{Age}

We use AGE as our explanatory variable for testing the acculturation hypothesis. This continuous variable is coded from -22 (18 years old, our youngest respondents) to 54 (94 years old, our oldest respondents). The advantage of this linear transformation is that the score " 0 " is about the average age in each country. We also need to take account of the main effects of age on party preference. For this we include three age groups (18-30, 31-50, and 51 and older) as covariates, since there appeared to be typically nonlinear relationships between age and party preference.

\section{Other Variables}

Although the impact of class mobility is our main theoretical concern, we must also take into account the impact of other relevant variables. Religion is particularly relevant, since we know, for example, that in Germany and the Netherlands Catholics tend to vote for right-wing parties, while there are religious differences in political behavior in Britain and the United States (Heath, Taylor, and Toka 1993). We divided church membership into five groups: Catholic, Protestant (Reformed), Orthodox Reformed (for the Netherlands only), other denomination, and no religion.

Given the importance of ethnicity for predicting political preference in the United States, we include ethnicity $(0=$ nonblack; $1=$ black) for the United States only. For the other three countries there were no minority ethnic groups large enough that ethnicity could sensibly be included as an independent variable.

A final important control variable is the year of interview, which we recoded into a set of dummies representing several periods: 1961-65, 1966-70, 1971-75, 1976-80, 1981-85, and 1986-90. We clearly need to control for the varying popularity of the political parties over the years.

${ }^{6}$ Coding the respondents into the EGP scheme takes two steps. First, we recode the original occupation codes into the International Standard Classification of Occupation (ISCO) codes (ILO 1969). Second, we translate these ISCO codes into EGP scores through the Ganzeboom, Luijkx, and Treiman (1989) recoding schema. 


\section{HOW TO MODEL MICRO EFFECTS OF INTERGENERATIONAL MOBILITY}

Our hypotheses distinguish between the political preferences of mobile and immobile individuals, and we therefore need a statistical model that corresponds to these substantive concerns. Conventional approaches that model political behavior as a function of origin and destination class will not be appropriate since the explanatory categories will include mixtures of mobile and immobile respondents. A substantively more appropriate model, in our view, is Sobel's $(1981,1985)$ diagonal reference model, ${ }^{7}$ in which the behavior of mobile respondents is modeled as a function of the behavior of the immobile respondents in the classes of origin and destination. The model therefore allows us to test specifically whether the mobile are closer in their political behavior to the immobile members of their class of destination or to the immobile members of their class of origin. ${ }^{8}$

The theoretical importance of taking the immobile as the reference has been suggested by Sorokin (1957, pp. 509-10), who argued that "if we want to know the characteristic attitudes of a farmer, we do not go to a man who has been a farmer for a few months, but go to a farmer who is a farmer for life." Even better, we would argue, go to a farmer who was born and bred a farmer. We can think of the immobile respondents as representing the core of the class and defining its norms and values to which newcomers may or may not acculturate.

Sobel's original model was designed for predicting a metric dependent variable. Given our binomial dependent variable, we fit instead of Sobel's model a logistic version. The logistic version can be expressed as follows:

$$
\begin{aligned}
\operatorname{prob}\left(Y_{i j k}=1\right) & =1 /\left(1+e^{-l i n}\right) ; \\
\operatorname{lin} & =p \alpha_{i}+(1-p) \alpha_{j}+\beta_{L} \operatorname{cov}_{L},
\end{aligned}
$$

where $Y_{i j k}=1$ if respondent $k$ in the $i j$ th cell of the mobility table has a left-wing preference and 0 if not. Subscript $j$ stands for father's class and $i$ for respondent's class. There is one parameter, $\alpha$, for each diagonal cell, representing the expected mean behavior of the core (the stable members) of each class. Parameters $p$ and $(1-p)$ are destination and origin weights that indicate the relative importance of the core destination

\footnotetext{
${ }^{7}$ Models of this type were originally known as diagonal mobility models. De Graaf and Ganzeboom (1990) argued that the label "diagonal reference model" is more appropriate.

${ }^{8}$ For a comparison of diagonal models with the conventional ones see Hendrickx et al. (1993).
} 
and origin classes. ${ }^{9}$ In equation (2) we estimate one $\beta$ coefficient for each covariate (cov). Consequently, if we have $L$ covariates, we have to estimate $L \beta$ parameters. ${ }^{10}$

\section{RESULTS: TESTS OF THE MICRO HYPOTHESES}

Table 2 presents the proportion of respondents with a left-wing political preference in each category of the intergenerational mobility table in each country (the different survey years being combined). We see that class has a clear nonlinear relationship with political preference. The petty bourgeois and farmers are by far the least likely to have a left-wing party preference in the Netherlands, Germany, and Britain, while in all cases the manual workers have the highest probability of a left-wing preference. Farmers in America are the most notable exception to these general propositions, and while there are similarities in the relationship between class and political preferences in all four countries, it has to be said that the similarity between the three European countries is particularly striking. The anomalous voting behavior of farmers in the United States is probably to be explained by the fact that the Democratic Party in the United States, unlike the left-wing parties in our three European countries, has traditionally endorsed farm-support measures.

The size of the class differences in left-wing politics, do, however, differ considerably. We can use the index of dissimilarity as an overall measure of class differences in voting behavior. ${ }^{11}$ The index proves to be

${ }^{9}$ We assume the restriction that $0 \leq p \leq 1$. The parameter $p$ does not have this restriction in the estimating procedure, however, because, in order to get the best parameter estimate in the iterative procedure, $p$ might get higher than 1 or lower than 0 . The diagonal reference models do not offer the appropriate design when $p$ does not fit in the $0-1$ interval, but this situation did not arise in any of the models used.

${ }^{10}$ Sobel's (1985) more general model allows a separate $\beta$ coefficient for each covariate for each diagonal reference cell $i$. The logistic version is

$$
\begin{aligned}
\operatorname{prob}\left(Y_{i j k}=1\right) & =1 /\left(1+e^{-l i n}\right) ; \\
l i n & =p\left(\alpha_{\imath}+\beta_{L i} \operatorname{cov}_{L}\right)+(1-p)\left(\alpha_{j}+\beta_{L i} \operatorname{cov}_{L}\right) .
\end{aligned}
$$

We have, however, no reason to assume a different relationship between our covariates and political preference for each diagonal cell. The advantage is that we have a more parsimonious model and can therefore rewrite eq. (3) into the simpler eq. (2).

${ }^{11}$ The usual method of measuring the level of class voting is the Alford index, but this index can be used only when the classes have been dichotomized. The index of dissimilarity does not require any restriction on the number of classes. The index is obtained by summing the differences between the two distributions (i.e., between the class distribution of left-wing voters and the class distribution of right-wing voters) and dividing by 2 . It thus measures the proportion who would have to change their political preferences to make the two distributions identical. The calculations in the text refer to the overall class distributions, including both mobile and immobile respondents, and have been calculated directly from table 2 . 
rather low in the United States at 15 and highest in Britain at 36, with the Netherlands (23) and Germany (22) in between.

Table 2 also shows, as previous research has done, that the political preferences of the mobile typically differ from those of the stable members of their class of destination. For example, in almost all cases individuals who are downwardly mobile into the manual working class display a lower level of left-wing political preference than do the stable members of the manual working class. Conversely, individuals who are mobile into the petty bourgeois tend to display a higher level of left-wing political preference than do the intergenerationally stable petty bourgeois.

We now move on to formal modeling of these data and tests of our hypotheses. To do this we combine the four national data files. We first fit baseline model A, including one parameter for the destination and origin weights $(p$ and $[1-p])$ and separate parameters for the religion, age, period, ${ }^{12}$ and ethnicity covariates. In this model we thus fit a common destination/origin weight but allow the covariates and the class parameters to differ in the four countries. The model therefore uses 63 parameters. ${ }^{13} \mathrm{~A}$ more parsimonious model that fitted common parameters for the classes and covariates could be explored, but since our primary interest is in the effects of mobility, a conservative strategy toward these covariates is appropriate.

The reason for the country-specific modeling of the class parameters is that we cannot assume the socioeconomic situation of a class to be identical in the four countries. Furthermore, the left-wing and right-wing political parties in our four countries may not be equally left- or rightwing in their political stances and may not equally espouse perceived class interests. For example, the Labour Party in Britain is substantially more left-wing than the Democratic Party in the United States. ${ }^{14}$ Since

\footnotetext{
${ }^{12} \mathrm{We}$ also fitted a dummy variable for each year instead of for each period. Using a dummy for each year, however, results in a large number of parameters. This is especially troublesome when we want to test whether the differences between the countries are significant. Since reducing these parameters by applying five-year periods did not change our results significantly, we preferred to apply these periods.

${ }^{13}$ We use one parameter for the weight, six parameters in each of the four countries for the diagonal reference categories, three parameters for religion in Britain, Germany, and the United States, and four for the Netherlands, two parameters for the age categories in each country, one for ethnicity in the United States, five for period in Britain, four for Germany and the Netherlands (since the 1961-65 period is not available in these countries), and three for the United States (where neither the 1961-65 nor 1966-70 periods are available).

${ }^{14}$ In both the U.S. and British National Election Studies of 1992, identical questions were asked about whether "the government should see to it that every person has a job and a good standard of living . . . [or] . . . should just let each person get ahead on their own." Respondents were asked for their own positions (on a seven-point scale) and for their perceptions of where the parties stood. In Britain $63 \%$ of respondents placed Labour on points 1 or 2 of the scale (the most left-wing positions) whereas in America only 30\% placed the Democrats on points 1 or 2 .
} 
TABLE 2

Percentage of Left-Wing Voters by Respondent's and Father's Class

\begin{tabular}{|c|c|c|c|c|c|c|c|}
\hline \multirow[b]{2}{*}{ Father's Class } & \multicolumn{7}{|c|}{ Respondent's Class } \\
\hline & $\begin{array}{l}\text { Service } \\
\text { Class }\end{array}$ & $\begin{array}{c}\text { Routine } \\
\text { Nonmanual }\end{array}$ & $\begin{array}{c}\text { Petty } \\
\text { Bourgeois }\end{array}$ & Farmers & $\begin{array}{l}\text { Manual } \\
\text { Workers }\end{array}$ & $\begin{array}{l}\text { Agricultural } \\
\text { Workers }\end{array}$ & $\begin{array}{c}\text { All } \\
\text { Workers }\end{array}$ \\
\hline \multicolumn{8}{|l|}{ Germany: } \\
\hline Service class ............... & $32(33)$ & $34(17)$ & $22(12)$ & $33(9)$ & $46(8)$ & $11(7)$ & 35 \\
\hline Routine nonmanual.... & $40(10)$ & $45(11)$ & $17(6)$ & $0(1)$ & $57(5)$ & $67(5)$ & 46 \\
\hline Petty bourgeois .......... & $28(10)$ & $28(11)$ & $12(33)$ & $0(2)$ & $37(6)$ & $52(2)$ & 28 \\
\hline Farmers..................... & $21(8)$ & $19(8)$ & $15(11)$ & $7(89)$ & $37(12)$ & $18(26)$ & 25 \\
\hline Manual workers ......... & $46(38)$ & $46(50)$ & $16(38)$ & $22(5)$ & $61(65)$ & $52(35)$ & 54 \\
\hline Agricultural workers .. & $36(1)$ & $52(3)$ & $21(1)$ & $0(2)$ & $60(4)$ & $52(25)$ & 55 \\
\hline All ......................... & $37(100)$ & $40(100)$ & $16(100)$ & $8(100)$ & $55(100)$ & $41(100)$ & 44 \\
\hline$N \ldots \ldots \ldots \ldots \ldots \ldots \ldots \ldots \ldots \ldots \ldots \ldots \ldots \ldots \ldots$ & 3,146 & 1,250 & 484 & 345 & 5,245 & 126 & 10,596 \\
\hline \multicolumn{8}{|l|}{ Great Britain: } \\
\hline Service class .............. & $13(32)$ & $22(21)$ & $14(13)$ & $9(10)$ & $35(6)$ & $10(10)$ & 19 \\
\hline Routine nonmanual.... & $15(8)$ & $33(11)$ & $25(5)$ & $0(0)$ & $42(3)$ & $0(0)$ & 26 \\
\hline Petty bourgeois .......... & $14(10)$ & $20(9)$ & $11(24)$ & $0(9)$ & $31(6)$ & $0(4)$ & 20 \\
\hline 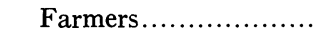 & $16(3)$ & $7(3)$ & $25(6)$ & $8(67)$ & $50(3)$ & $24(13)$ & 27 \\
\hline Manual workers ......... & $27(46)$ & $39(54)$ & $21(49)$ & $0(10)$ & $61(76)$ & $40(26)$ & 50 \\
\hline Agricultural workers . & $15(2)$ & $34(3)$ & $34(3)$ & $58(4)$ & $55(5)$ & $41(47)$ & 47 \\
\hline All.......................... & $20(100)$ & $32(100)$ & $19(100)$ & $9(100)$ & $56(100)$ & $34(100)$ & 40 \\
\hline$N$ & 1,725 & 507 & 483 & 113 & 3,244 & 96 & 6,168 \\
\hline
\end{tabular}




\begin{tabular}{|c|c|c|c|c|c|c|c|}
\hline \multicolumn{8}{|c|}{ Netherlands: } \\
\hline Service class ............. & $21(36)$ & $26(23)$ & $24(11)$ & $26(3)$ & $38(10)$ & $22(6)$ & 25 \\
\hline Routine nonmanual.... & $28(13)$ & $34(15)$ & $13(4)$ & $50(1)$ & $46(6)$ & $33(2)$ & 33 \\
\hline Petty bourgeois ......... & $19(13)$ & $28(14)$ & $7(45)$ & $6(4)$ & $37(11)$ & $25(5)$ & 23 \\
\hline Farmers................... & $18(10)$ & $16(8)$ & $11(14)$ & $5(84)$ & $27(12)$ & $12(37)$ & 16 \\
\hline Manual workers ......... & $37(26)$ & $39(37)$ & $30(21)$ & $30(4)$ & $53(55)$ & $45(20)$ & 46 \\
\hline Agricultural workers .. & $31(3)$ & $43(4)$ & $23(5)$ & $32(5)$ & $51(7)$ & $37(30)$ & 42 \\
\hline All ........................ & $26(100)$ & $32(100)$ & $15(100)$ & $8(100)$ & $46(100)$ & $28(100)$ & 33 \\
\hline$N \ldots \ldots \ldots \ldots \ldots \ldots \ldots \ldots \ldots$ & 2,443 & 1,183 & 390 & 404 & 2,511 & 155 & 7,086 \\
\hline \multicolumn{8}{|c|}{ United States: } \\
\hline Service class ............. & $31(38)$ & $31(32)$ & $23(21)$ & $9(3)$ & $40(15)$ & $14(12)$ & 33 \\
\hline Routine nonmanual.. & $35(7)$ & $21(10)$ & $49(3)$ & $0(1)$ & $34(4)$ & $0(0)$ & 33 \\
\hline Petty bourgeois .......... & $33(7)$ & $54(7)$ & $39(15)$ & $54(2)$ & $43(7)$ & $43(4)$ & 41 \\
\hline Farmers..................... & $33(12)$ & $39(10)$ & $39(18)$ & $34(84)$ & $48(19)$ & $43(46)$ & 41 \\
\hline Manual workers ......... & $35(36)$ & $42(41)$ & $36(42)$ & $38(8)$ & $49(53)$ & $29(24)$ & 43 \\
\hline Agricultural workers .. & $40(1)$ & $95(1)$ & $73(2)$ & $72(2)$ & $60(3)$ & $63(14)$ & 62 \\
\hline 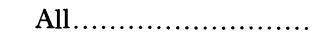 & $33(100)$ & $38(100)$ & $35(100)$ & $35(100)$ & $46(100)$ & $39(100)$ & 40 \\
\hline $\boldsymbol{N}$ & 3,148 & 930 & 447 & 367 & 4,393 & 87 & 9,372 \\
\hline
\end{tabular}

NoTE.—Percentages of inflow mobility are given in parentheses. 


\section{American Journal of Sociology}

the level of class voting is likely to depend on the congruence between perceived class interests and perceived party policies, we must clearly take into account relevant national differences. By allowing the diagonal parameters to differ between countries, we control for these differences. Similar considerations apply to the covariates and, for example, to the well-known national differences in the role of religion in voting behavior.

In this baseline model, the comparison of the origin and destination weights allows us to assess our first hypothesis at the microlevel, namely the economic hypothesis. In table 3 we report the fit $\left(G^{2}=-2 \log \right.$ likelihood) of this model. The quantity $-2 \log$ likelihood does not have a straightforward interpretation, but the goodness of fit of one model relative to another can be assessed using the fact that, provided the two models in question are nested, the difference has a chi-square distribution with degrees of freedom equal to the difference between the two models in the number of their parameters.

TABLE 3

Nested Logistic Diagonal Reference Models for the Relative INFLUENCE OF RESPONDENT'S ClasS AND FatheR's ClasS on Respondent's Political Preference

\begin{tabular}{|c|c|c|c|}
\hline Model and Description & $G^{2}$ & BIC & $d f$ Used \\
\hline \multirow{2}{*}{ A-Baseline ......................................................... } & $39,194.3$ & $-306,023.0$ & 63 \\
\hline & $-\Delta G^{2}$ & $\Delta \mathrm{BIC}$ & $\Delta d f$ Used \\
\hline B-Acculturation . & 39.8 & -29.4 & 1 \\
\hline 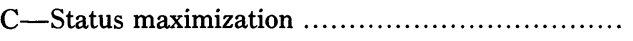 & 39.8 & -19.0 & 2 \\
\hline D-Status maximization ............... & 43.8 & -23.0 & 2 \\
\hline 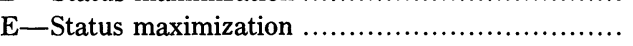 & 44.4 & -13.2 & 3 \\
\hline \multicolumn{4}{|l|}{ Country-specific models: } \\
\hline A1-Baseline: Country-specific weight ............. & 2.8 & 28.4 & 3 \\
\hline $\begin{array}{l}\text { B1-Acculturation: Country-specific weight ....... } \\
\text { B2-Acculturation: Country-specific }\end{array}$ & 40.4 & 1.2 & 4 \\
\hline 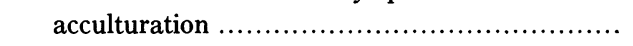 & 46.7 & -5.1 & 4 \\
\hline 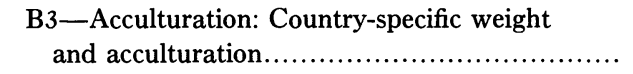 & 48.5 & 24.4 & 7 \\
\hline \multicolumn{4}{|l|}{ Class-specific models: } \\
\hline A2-Baseline: Class-specific weight .................. & 11.4 & 40.7 & 5 \\
\hline A3-Baseline: Class- and country-specific weight & 47.1 & 192.4 & 23 \\
\hline B4-Acculturation: Class-specific weight ........... & 52.8 & 9.7 & 6 \\
\hline $\begin{array}{l}\text { B5-Acculturation: Class-specific acculturation... } \\
\text { B6-Acculturation: Class-specific weight and }\end{array}$ & 49.6 & 12.9 & 6 \\
\hline acculturation ...................................... & 59.3 & 55.2 & 11 \\
\hline
\end{tabular}

Note. $-N=33,222$. Results controlled for respondent's religious denomination and age and for the year of the survey. Equations for the models are given in appendix A. The $G^{2}, \mathrm{BIC}$, and $d f$ used are reported for the baseline model; for the nested models the reduction in $G^{2}$ (against the $d f$ ) and BIC compared to the baseline model are reported. 
The first model to be compared with this baseline model is the one including an acculturation effect. The acculturation hypothesis predicts that the older one is, the larger will be the influence of the destination class relative to that of the origin class. In other words, this hypothesis implies that the weight parameters vary according to the length of time that one is a member of a class. Model B therefore includes an interaction between age and the origin and destination weights. The equation of this model is

$$
\begin{aligned}
\operatorname{prob}\left(Y_{i j k}=1\right)= & 1 /\left(1+e^{-l i n}\right) \\
l i n= & (p+\delta p \times \mathrm{AGE}) \alpha_{i} \\
& +[(1-p)-\delta p \times \mathrm{AGE}] \alpha_{j}+\beta_{L} \operatorname{cov}_{L} .
\end{aligned}
$$

According to this model the destination weight increases by $\delta p$ for each extra year of age. Conversely, the origin weight decreases by $\delta p$ for each extra year of age. This symmetry means that $[p+(1-p)]$ still sums to 1 (see De Graaf 1991).

On the standard criteria, this acculturation model results in a significant improvement compared to our baseline model. Given our very large sample sizes, it can be questioned whether the conventional criteria are altogether appropriate, and we therefore report the BIC statistic too (Raftery 1986), which adjusts the fit statistic by sample size and degrees of freedom. The more negative the BIC, the better the fit of the model. Table 3 shows that both on the $G^{2}$ statistic $\left(-\Delta G^{2} / \Delta d f\right)$ and the BIC criterion, the acculturation hypothesis (model $\mathrm{B}$ ) is to be preferred to the baseline model. ${ }^{15}$

Next, the status maximization hypothesis predicts that for the downwardly mobile the process of acculturation will take longer than it does for the upwardly mobile. To test this, we have to define a variable (UP) that indicates whether one is upwardly mobile or downwardly mobile. Determining the direction of mobility is not straightforward, given the categorical class scheme. We assume that those who move from any other class to the service class are upwardly mobile (i.e., those with origin class $2,3,4,5$, or 6 and destination class 1 have a score of " 1 " and others have a score of " 0 ").

The next question is how to test this hypothesis, since there are three

\footnotetext{
${ }^{15}$ Since the diagonal model can also be considered as a restricted version of Duncan's (1966) square additive model, we also tested the logistic version of the square additive model. This model resulted in a BIC of $-305,886$, while using $16 d f$ more than the diagonal model. The baseline diagonal model resulted in a BIC of $-306,023$. Therefore, besides theoretical reasons, we also prefer the diagonal version instead of the conventional model for statistical reasons.
} 
possible interpretations (see Nieuwbeerta and De Graaf 1993). One interpretation is that the rate of adjustment is the same among the upwardly and downwardly mobile and that it is the extent of adjustment that differs. Given this interpretation we can model an additional interaction effect on the weight parameters. This is model $\mathrm{C}$ in table $3 .{ }^{16} \mathrm{~A}$ second interpretation is that the rate of acculturation is simply slower for the downwardly mobile. Because the upwardly mobile gain status, they will adapt faster to their class of destination than will the downwardly mobile. We can test this interpretation by adding a second-order interaction term between the variables UP and AGE. This is done in model D in table 3. A third interpretation is that the first two interpretations are simultaneously valid. This interpretation is expressed in model $\mathrm{E}$ in table 3 .

As the BIC statistic shows, none of these three interpretations is preferable to the acculturation model $\mathrm{B}$. We should, therefore, reject the hypothesis that the downwardly mobile and upwardly mobile differ in their acculturation pattern. ${ }^{17}$ This result contradicts earlier empirical studies (for an overview see Janowitz [1970]) but is in line with the more recent empirical results of De Graaf and Ultee (1990), Weakliem (1992), and Nieuwbeerta and De Graaf (1993).

The conclusion so far is that the acculturation model $\mathrm{B}$ gives the best representation of the data. We should note that similar nested model comparisons for each country separately also showed the acculturation model to be preferable. The acculturation model B assumes that there are no differences between our four countries in the strength of the destination and acculturation effects. This assumption, however, may not be warranted, and there may be country-specific mobility effects in the same way that there may be some country-specific effects of class, religion, or period. Our next step, therefore, is to test whether there are differences in these effects between countries. The first country-specific model that

${ }^{16}$ Given our definition of upward and downward mobility, we have a large number of respondents who are mobile but neither upwardly nor downwardly. In models C, $\mathrm{D}$, and $\mathrm{E}$ we included an interaction term that only models an extra destination effect for the upwardly mobile. A more strict test of our hypothesis would be to include an extra interaction term for the downwardly mobile as well. This would imply that the reference category comprises those who are mobile but neither upward nor downward. However, these more complex models did not result in any significant improvement.

${ }^{17}$ We would like to note that the statement "We should, therefore, reject the hypothesis that . . ." is not a standard statement, because the hypothesis being rejected is an alternative hypothesis. Standard hypothesis testing allows one only to reject a null hypothesis; in this framework one cannot reject an alternative hypothesis, but can only fail to reject the null. In the Bayesian approach that underlies BIC, however, it is perfectly valid to say that the data reject an alternative hypothesis, since they provide evidence for the null. We are very grateful to an $A J S$ reviewer for this observation. 
we test assumes that the weight parameter varies among the countries (model A1 in table 3). This model does not lead to a significant improvement, either on the $G^{2}$ or the BIC criterion, over model A. We next turn to variations on the acculturation model (i.e., models B1, B2, and B3). These models fit different weight parameters or different acculturation parameters for each country. As table 3 shows, none of these models results in significant improvement in fit compared with model B. ${ }^{18}$ Hence, our conclusion is that both destination/origin effects and acculturation effects are similar in all four countries under investigation.

The parameter estimates of our preferred model (acculturation model B) are presented in table 4 . The estimates for the covariates indicate that religious denomination is an important predictor in all four countries. In particular the Orthodox Reformed in the Netherlands have a relatively low probability of having a left-wing political preference. Age has no significant impact in Germany, the Netherlands, and the United States. Not unexpectedly, in the United States blacks have a higher chance of having a left-wing preference than nonblacks.

The estimates of the diagonal reference parameters are presented in table 4 as well. In order to help the reader interpret the parameter estimates, we also calculate the predicted probability of having a left-wing preference within each reference class for respondents who are 18-25 years old, nonblack, and nonreligious in the reference period. The diagonal parameters show that, with the exception of the United States, the intergenerationally stable petty bourgeois and the farmers have the lowest probability of having a left-wing preference. In all four countries the manual workers and the agricultural workers have the highest probability of having a left-wing preference.

Our main interest, however, is in the weight parameter $p$ and the acculturation parameter $\delta p$. The weight parameter is $.585(\mathrm{SE}=.018)$ and the acculturation parameter is $.005(\mathrm{SE}=.001)$. This suggests that the cumulative impact of acculturation over the life span is indeed substantial. Thus our preferred model suggests that for 18 year olds (coded -22 on our AGE variable) in all four countries the relative destination weight is $.585-22 \times .005$, that is .475 , and the origin weight is .525 . This implies that for our youngest respondents the effect of origin is slightly more important than the effect of their current class. By the time

\footnotetext{
${ }^{18}$ We experimented with various combinations of country-specific destination weights and country-specific acculturation effects. Since our analyses for each country separately showed, especially for the United States, a relatively strong acculturation effect, we tested, for example, for U.S. exceptionalism. The upshot of all these nested model comparisons is that the simple acculturation model B fits the data best, both by the $G^{2}$ and BIC standards.
} 
TABLE 4

Parameter Estimates of the Acculturation Model B

\begin{tabular}{|c|c|c|c|c|}
\hline & Germany & Great Britain & Netherlands & United States \\
\hline & \multicolumn{4}{|c|}{$\alpha$ : Political Preference of Immobile } \\
\hline Service class ................ & $\begin{array}{c}-.753^{* * *} \\
(32)\end{array}$ & $\begin{array}{c}-2.017 * * * \\
(12)\end{array}$ & $\begin{array}{c}-.655^{* * *} \\
(34)\end{array}$ & $\begin{array}{c}-.544 * * \\
(20)\end{array}$ \\
\hline Routine nonmanual....... & $\begin{array}{c}-.416^{*} \\
(40)\end{array}$ & $\begin{array}{c}-1.139^{* * *} \\
(24)\end{array}$ & $\begin{array}{r}-.054 \\
(49)\end{array}$ & $\begin{array}{r}-.353 \\
(24)\end{array}$ \\
\hline Petty bourgeois ............ & $\begin{array}{c}-2.087 * * * \\
(11)\end{array}$ & $\begin{array}{c}-2.308^{* * *} \\
(9)\end{array}$ & $\begin{array}{c}-1.193 * * * \\
(24)\end{array}$ & $\begin{array}{r}-.323 \\
(24)\end{array}$ \\
\hline Farmers..................... & $\begin{array}{c}-2.325 * * * \\
(8)\end{array}$ & $\begin{array}{c}-2.141^{* * *} \\
(10)\end{array}$ & $\begin{array}{c}-1.620^{* * * *} \\
(17)\end{array}$ & $\begin{array}{r}-.255 \\
(33)\end{array}$ \\
\hline Working class .............. & $\begin{array}{l}.456^{* *} \\
(61)\end{array}$ & $\begin{array}{l}.339^{*} \\
(58)\end{array}$ & $\begin{array}{l}.987^{* * *} \\
(73)\end{array}$ & $\begin{array}{r}.181 \\
(37)\end{array}$ \\
\hline \multirow[t]{2}{*}{ Agricultural laborers ..... } & $\begin{array}{r}-.074 \\
(48) \\
\end{array}$ & $\begin{array}{r}-.555 \\
(37) \\
\end{array}$ & $\begin{array}{r}442 \\
(61) \\
\end{array}$ & $\begin{array}{r}.370 \\
(38) \\
\end{array}$ \\
\hline & \multicolumn{4}{|c|}{$\beta$ : Effect of Covariate on Political Preference } \\
\hline \multicolumn{5}{|l|}{ Religion: } \\
\hline Catholic................. & $-.953^{* * *}$ & $.444^{*}$ & $-1.513 * * *$ & -.217 \\
\hline Reformed/Protestant... & -.227 & $-.260 *$ & $-.783 * * *$ & $-.656^{* * *}$ \\
\hline Orthodox Reformed ... & $\ldots$ & $\ldots$ & $-2.749 * * *$ & $\ldots$ \\
\hline Other .................... & -.337 & $.609 *$ & $-.632 *$ & .382 \\
\hline No religion .............. & 0 & 0 & 0 & 0 \\
\hline \multicolumn{5}{|l|}{ Age: } \\
\hline $18-30 \ldots \ldots \ldots \ldots \ldots \ldots$ & .135 & -.123 & .044 & -.151 \\
\hline $31-50^{a} \ldots \ldots \ldots \ldots \ldots \ldots$ & 0 & 0 & 0 & 0 \\
\hline $51+\ldots \ldots \ldots \ldots \ldots \ldots \ldots \ldots$ & -.062 & $-.293^{*}$ & .259 & .130 \\
\hline \multicolumn{5}{|l|}{ Ethnicity: } \\
\hline Nonblack $^{\mathrm{a}} \ldots \ldots \ldots \ldots \ldots$ & . . & . & $\ldots$ & 0 \\
\hline Black ................... & $\ldots$ & . & $\ldots$ & $1.697 * * *$ \\
\hline \multicolumn{5}{|l|}{ Period: } \\
\hline $1961-65 \ldots \ldots \ldots \ldots \ldots \ldots$ & $\ldots$ & $.691 * * *$ & $\ldots$ & $\ldots$ \\
\hline $1966-70 \ldots \ldots \ldots \ldots \ldots \ldots$ & $1.023 * * *$ & $.849 * * *$ & -.248 & $\ldots$ \\
\hline $1971-75 \ldots \ldots \ldots \ldots \ldots$ & $.614 * * *$ & $.524 * *$ & .305 & -.164 \\
\hline $1976-80 \ldots \ldots \ldots \ldots \ldots$ & $.575^{* * *}$ & .175 & .143 & $.490 * * *$ \\
\hline $1981-85^{\mathrm{a}} \ldots \ldots \ldots \ldots \ldots \ldots$ & 0 & 0 & 0 & 0 \\
\hline $1986-90 \ldots \ldots \ldots \ldots \ldots \ldots$ & $.408 * *$ & -.082 & $-.417 * * *$ & $-.309 * *$ \\
\hline
\end{tabular}

NotE.-Destination weight $(p)$ equals $.585^{* * *}$, effect of age on destination weight $(\delta p)$ equals $.005^{*}$. Numbers in parentheses report probability of having a left-wing preference within the reference category.

${ }^{\text {a }}$ Reference category.

$* P<.05$.

$* * P<.01$

$* * * P<.001$. 
they have reached 65 years of age (coded 25 on our AGE variable), the relative destination effect becomes $.585+25 \times .005$, that is .710 , and the origin effect becomes .290 . Although these figures indicate that the destination effect is over twice the size of the origin effect, origin still has some impact on the political preferences of 65 -year-olds.

\section{RESULTS: MACRO EFFECTS OF INFLOW MOBILITY}

\section{Compositional Effect}

Table 2 confirms that a compositional effect of social mobility is present and suggests that intergenerational mobility diminishes the "democratic class struggle." For example, in Britain $61.2 \%$ of the stable members of the manual working class had a left-wing political preference, whereas the figure for the class as a whole falls to $56.4 \%$. Hence, the compositional effect amounts to $-4.8 \%$. Conversely, the proportion of the service class as a whole with a left-wing preference (19.7\%) is greater than that in the core service class (13.1\%). In this case the compositional effect is $6.6 \%$. In general, then, we find that the class differences down the main diagonal (that is, the differences between the core classes) are greater than the differences between the classes taken as a whole. This is the case for all three European countries, although it is less evident in the case of America. (Since class has a weaker effect on voting behavior in the United States, the compositional effects of social mobility, other things being equal, are likely to be smaller too.)

Clearly, then, there are compositional effects, but as we argued earlier the size of these effects will depend not only on the amount of inflow but also on the political complexion of that inflow. For example, in the case of Britain $24 \%$ of the manual class were newcomers coming from other class origins, but the proportion of these newcomers with left-wing political preferences was only .41 , rather different from the proportion (.61) of stable members who had left-wing political preferences. In the service class, on the other hand, $68 \%$ were newcomers, but their political preferences were not so deviant from those of the stable members: $23 \%$ of newcomers to the service class had a left-wing political preference, compared with $13 \%$ of the stable members. The overall compositional effect on the service class is thus $(23 \%-13 \%) \times 68 \% / 100=7 \%$ (which is of course the same as the difference between the diagonal figure and the figure for all service-class workers in table 2), while the overall compositional effect in the manual class is $(41 \%-61 \%) \times 24 \% / 100=-5 \%$. The greater volume of inflow into the service class, then, is partly canceled out by the lesser political deviance of that inflow, and the net result is that the compositional effect on the service class is not notably large, 
despite the heterogeneity in its social origins. Similar results can be obtained for the other European countries. Indeed, in Germany the compositional effect in the service class $(5 \%)$ is actually smaller than that in the manual working class $(-6 \%)$ despite the much greater volume of mobility into the service class.

This compositional account ignores any processes of mutual interaction and influence between the stable and mobile members of a class. It simply takes the political preferences of the mobile and immobile as given. We now move on to consider whether we can find any evidence for contextual processes that might help to account for the political preferences of the mobile and immobile respectively.

\section{Contextual Effect for the Mobile}

Our first contextual hypothesis states that a class with a low level of inflow mobility (and therefore a high level of demographic identity) will have a greater impact on newcomers than will a class with a higher level of inflow mobility. First, however, we must investigate whether the social classes vary in their impact on newcomers at all before we move on to test whether the differing impacts on newcomers can be explained by the rates of inflow mobility.

To calculate the impact of a class on newcomers, we fit models A2 and A3 (see table 3). Model A2 fits a separate weight parameter for each destination class. The class-specific weight parameters that we obtain from this model thus give us estimates of the different impacts of the classes on newcomers. However, as we can see from table 3, this model does not yield a significant improvement in fit over the baseline model A. Model A3, which allows each country to have different class-specific weights, is no more successful.

We have also experimented with various acculturation models that fit class-specific effects (models B4-B6 in table 3). For example, in model B5 we test whether it is the acculturation process (that is, the interaction with age) that varies between classes. None of our investigations, ${ }^{19}$ however, yielded a class-specific version that unambiguously displayed improved fit compared with the corresponding class-uniform model. The BIC statistic clearly suggests that model B is the best, while the standard hypothesis tests indicate that $\mathrm{B} 4$, with class-specific weight parameters, and B6, with class-specific weight and acculturation parameters, do fit significantly better $\left(\mathrm{B}-\mathrm{B} 4: G^{2}=13.0, d f=5\right.$; B $-\mathrm{B} 6: G^{2}=19.5$,

${ }^{19}$ For the sake of simplification, we present only a few of the models we tested. 
$d f=10$ ). For the moment we should perhaps use the Scottish judicial verdict of "not proven." At any rate, we do not yet have sufficiently good grounds to proceed with tests of the contextual hypothesis for the mobile; if there are no class differences in impacts on newcomers, there is nothing for us to explain, and we must a fortiori reject our first contextual hypothesis for the mobile.

\section{Contextual Effect for the Immobile}

Our second contextual hypothesis implies that the extent and political character of the inflow mobility will influence the political preferences of the stable class members. Here, therefore, our interest is in explaining the variations in the political preferences of the intergenerationally stable members of each class. There are, as we saw in table 2, large differences in the political preferences of these core classes, but we must of course recognize that these are likely to be due to the distinct material circumstances and interests of the classes and not solely to mobility patterns. We take this into account in our modeling by allowing each class within each nation to have its own "natural" level of left-wing preferences. (This is why we also estimated country-specific diagonal cells for our models in table 3). In this way we can test whether rates of inflow mobility can account for variations around this "natural" level.

The essence of our model, then, is that the level of left-wing preference in a particular year among the stable members of a given class in a country is to be explained by the level of inflow into that class in that year. In order to take account of the political complexion of the inflow, we have to weight the inflow. The basic ideas can be represented by:

$$
\pi_{y i n}=\mathrm{PREF}_{i n}+\gamma\left(\mathrm{INFLOW}_{y i n} \times \mathrm{WEIGHT}_{i n}\right)+E_{y i n},
$$

where $\pi_{y i n}$ is the proportion of the stable members in class $i$, year $y$, and nation $n$ who support a left-wing party; $\mathrm{PREF}_{\text {in }}$ gives the "natural" level of left-wing political preferences among the stable members of class $i$ in nation $n$ (and is measured by [6 $64-1] 23$ dummy variables); INFLOW $_{y i n}$ represents the proportion of class $i$ in nation $n$ and year $y$ who were intergenerationally mobile (that is, who came from social origins other than $i$ ). There are many possible procedures that could be used for calculating WEIGHT ${ }_{i n}$, but the one reported here uses the political preferences of the stable members of the origin classes. ${ }^{20}$

${ }^{20}$ A numerical example may clarify our procedure. In calculating the left-wing inflow mobility into the service class in Britain in 1964, we first take the actual proportions of the service class in Britain in 1964 who were mobile from the other five class origins. From the manual class, $47.2 \%$ were mobile. We then weight this proportion by .612 (the proportion of the stable members of the working class who had a left-wing political preference in the combined British data set, as shown in table 2). From the 
In this model the unit of analysis is not the individual but the class (within a given nation in a given year). We therefore have 282 observations (and we naturally must weight these observations according to the number of individuals on which they are based). Our dependent variable is the proportion of that class with left-wing political preferences and is therefore a continuous variable (and is approximately normally distributed). We can therefore use linear regression. The model explains $29 \%$ of the variance, but the key parameter of interest, the parameter $\gamma$, is nowhere near significant $(t=1.1)$. We therefore have to reject the hypothesis that the more left-wing mobility there is into a class, the more likely are the immobile members to have a left-wing political preference.

Unlike our earlier microlevel analyses, the macrolevel model represented in equation (4) fails to control for the other characteristics of the stable class members, such as their religion, age, and ethnicity. However, further modeling that incorporates controls for these characteristics reaches essentially the same conclusions. ${ }^{21}$

agricultural worker class, $4.1 \%$ were mobile, and we weighted this proportion by .409. The weighted inflow to the service class in Britain in 1964 thus becomes $4.1 \%$ $\times .409+47.2 \% \times .612+4.2 \% \times .079+11.3 \% \times .113+7.4 \% \times .326=$ $34.584 \%$. These weights must be kept constant over time; if we allow them to vary each year, we introduce a potential risk of circularity into the model: In some years, quite independent of levels of mobility, there may be across-the-board increases in left-wing political preferences affecting the mobile and the stable alike. Weights that were allowed to vary each year might thus be correlated with the yearly variations in the dependent variable. We are grateful to an $A J S$ reviewer for suggesting this method of constructing our explanatory variable.

${ }^{21}$ One way to control for these individual-level characteristics is to use a multilevel model (Burstein, Linn, and Capell 1978; Goldstein 1987). The first level becomes an individual-level model in which we use exactly the same control variables as we did earlier in the article. Our contextual model, expressed in eq. (4), then becomes the second level. Within the multilevel framework, the dependent variable in this second level is no longer the observed proportion with a left-wing preference but is the intercept (for the given level-2 unit) from the level-1 equation. This intercept can be thought of as the predicted probability of supporting a left-wing political party in that particular level-2 unit for someone with the baseline individual characteristics. More formally, the level-1 equation is

$$
Y_{i n y k}=\zeta_{i n y}+\eta_{L n} \operatorname{cov}_{L n}+E_{i n y k}
$$

where $\zeta_{\text {iny }}$ represents the intercepts for the level-2 units and there are $L$ covariates, as in eq. (2). The level-2 equation is

$$
\zeta_{i n y}=\mathrm{PREF}_{i n}+\theta\left(\mathrm{INFLOW}_{i n y} \times \mathrm{WEIGHT}_{i n}\right)+u_{i n y} .
$$

This is what is known as a random intercepts model. As with microlevel analysis, it is appropriate to employ a logistic reformulation of these equations, and this can be done easily. The analyses were conducted using the VARCL computer program. Within VARCL, eqq. (5) and (6) are estimated simultaneously on the basis of the 


\section{CONCLUSIONS AND DISCUSSION}

In this article we modeled the impact of intergenerational class mobility on political preference. For this purpose we used 55 cross-sectional data sets representing the United States, Britain, Germany, and the Netherlands. These data cover the period 1964-90. We distinguished hypotheses on the micro as well as the macro level. On the micro level we tested three hypotheses using the design of Sobel's diagonal reference models. We found that an acculturation model resulted in the best fit. Furthermore, a test of possible differences between the four countries revealed that an acculturation model with the same destination weight and acculturation process in all four countries gave the best fit.

This commonality in the relative effects of mobility is a surprising and important result in its own right. We might a priori expect to find substantial differences between the more traditional societies of Europe, where class distinctions are believed to be more deeply ingrained, than in a new society such as the United States. In the United States we might have anticipated that the relative effects of origin might be smaller and the acculturation process more rapid. But despite our large data set, we could not reject the hypothesis that the same model applied to all four of our countries.

To be sure, there are large absolute differences between our four countries in the size of the class effects on voting, and our results are the same as those of other scholars who have shown that class voting is weaker in the United States. The important finding is that the relative importance of origin and destination for political preferences is not significantly different in America. This result mirrors findings about the mobility process itself: While absolute rates of mobility tend to be higher in the United States, relative mobility rates, or fluidity (as measured by the odds ratios), is not exceptionally high in the United States (Erikson and Goldthorpe 1985).

On the macro level we tested one compositional and two contextual hypotheses. Our results did indeed show the force of compositional arguments. In general, mobility tends to weaken the "democratic class struggle," but the effects of the amount of inflow mobility depend on the political complexion of that inflow. While the service class, for example, is a great deal more heterogeneous in its social origins than is the manual working class in all four of our countries, we found that in the European ones this heterogeneity was largely canceled out by the relatively rightwing character of the inflow into the service class.

maximum-likelihood procedure (for a more detailed account, see Longford [1988]). However, the results of the multilevel logistic analysis are essentially the same as those of the simpler analysis reported in the text, and the parameter for the weighted inflow, $\theta$, remains nonsignificant $(t=0.43)$. 
While the occurrence of compositional effects is not, perhaps, very surprising, it is more interesting to observe that they fail to account for the relatively low class polarization in the United States. Even when we look at the stable members of each class in the United States (the diagonal cells), we find that class differences are small.

While the compositional effects of social mobility can clearly be quite substantial, however, our article found little evidence for the more subtle ways in which mobility can reduce class polarization through contextual processes. We were not able to provide convincing support for contextual effects either on the mobile or on the immobile. One possible explanation for this is that contextual class processes simply are weak in contemporary industrial societies. Contextual processes of the kind we envisaged may require stable communities with fairly clear boundaries, high levels of in-group interaction, and low levels of out-group interaction. These conditions may be met for some social groups in contemporary society but may be weak or absent for social classes. For example, there does seem to be some evidence for contextual school effects, but it is likely that schoolchildren interact much more with pupils from the same school than with pupils from other schools. The social conditions under which contextual effects emerge may, therefore, not be satisfied in the case of social classes.

Alternatively, it may be that we have focused on the wrong aspects of class. For example, patterns of intragenerational mobility and stability may be more important than those of intergenerational mobility. Intergenerational mobility tables give us only a snapshot; some people who, in the snapshot, are intergenerationally stable may subsequently move. This is particularly likely in a class like the routine nonmanual workers, membership of which tends to be rather transitory. Conversely, intergenerationally mobile newcomers to the service class may have high probabilities of intragenerational stability once they have arrived. It may therefore be that the core of the class, which defines its norms and values, will consist of those who are indeed long-term members, but intergenerational stability may not be a good indicator of long-term membership.

Another possibility is that the processes we hypothesized do occur but over a much longer time scale. The more diffuse the patterns of social interaction are, the longer it may take for mobility rates to shape class processes. Processes that may emerge in a matter of months under the conditions of intensive within-group interaction that may characterize schools may take a generation to emerge under the conditions that characterize social classes. Our evidence suggests that the process of individual acculturation to the political preferences of the destination class is a gradual and long-term process, continuing over the life span. The same may well be true of the contextual processes. 
It is too soon, then, to reject the contextual theories of class formation and the expressive theories of voting behavior with which we associated them. After all, the existence of acculturation is difficult to explain except by the effects of social context. Ideally, too, we would use direct measures of people's patterns of social interaction in addition to the indirect measures based on mobility rates used in this article. What we hope to have shown is that the older tradition of macrosociological thinking about the effects of mobility raises questions that are both researchable and are of continuing interest.

\section{APPENDIX A}

Definitions of Models

\section{General Models}

$$
\begin{aligned}
\text { A: }: \text { lin }= & (p) \alpha_{i n}+(1-p) \alpha_{j n}+\beta_{L} \operatorname{cov}_{L} \\
\text { B: lin }= & (p+\delta p \times \mathrm{AGE}) \alpha_{i n} \\
& +[(1-p)-\delta p \times \mathrm{AGE}] \alpha_{j n}+\beta_{L} \operatorname{cov}_{L} \\
\mathrm{C}: \operatorname{lin}= & (p+\delta p 1 \times \mathrm{AGE}+\delta p 2 \times \mathrm{UP}) \alpha_{i n} \\
& +[(1-p)-\delta p 1 \times \mathrm{AGE}-\delta p 2 \times \mathrm{UP}] \alpha_{j n}+\beta_{L} \operatorname{cov}_{L} \\
\text { D: }: \text { in }= & (p+\delta p 1 \times \mathrm{AGE}+\delta p 2 \times \mathrm{UP} \times \mathrm{AGE}) \alpha_{i n} \\
& +[(1-p)-\delta p 1 \times \mathrm{AGE}-\delta p 2 \times \mathrm{UP} \times \mathrm{AGE}] \alpha_{j n}+\beta_{L} \operatorname{cov}_{L} \\
\mathrm{E}: l i n= & (p+\delta p 1 \times \mathrm{AGE}+\delta p 2 \times \mathrm{UP}+\delta p 3 \times \mathrm{UP} \times \mathrm{AGE}) \alpha_{i n} \\
& +[(1-p)-\delta p 1 \times \mathrm{AGE}-\delta p 2 \times \mathrm{UP}-\delta p 3 \times \mathrm{UP} \times \\
& \mathrm{AGE}] \alpha_{j n}+\beta_{L} \operatorname{cov}_{L}
\end{aligned}
$$

\section{Nation-Specific Models}

$$
\begin{aligned}
\text { A1: lin }= & p_{n} \alpha_{i n}+\left(1-p_{n}\right) \alpha_{j n}+\beta_{L} \operatorname{cov}_{L} \\
\text { B1: lin }= & \left(p_{n}+\delta p \times \mathrm{AGE}\right) \alpha_{i n} \\
& +\left[\left(1-p_{n}\right)-\delta p \times \mathrm{AGE}\right] \alpha_{j n}+\beta_{L} \operatorname{cov}_{L} \\
\text { B2: lin }= & \left(p+\delta p_{n} \times \mathrm{AGE}\right) \alpha_{i n} \\
& +\left[(1-p)-\delta p_{n} \times \mathrm{AGE}\right] \alpha_{j n}+\beta_{L} \operatorname{cov}_{L} \\
\text { B3: lin }= & \left(p_{n}+\delta p_{n} \times \mathrm{AGE}\right) \alpha_{i n} \\
& +\left[\left(1-p_{n}\right)-\delta p_{n} \times \mathrm{AGE}\right] \alpha_{j n}+\beta_{L} \operatorname{cov}_{L}
\end{aligned}
$$




\section{Class-Specific Models}

$$
\begin{aligned}
\text { A2: lin }= & p_{i} \alpha_{i n}+\left(1-p_{i}\right) \alpha_{j n}+\beta_{L} \operatorname{cov}_{L} \\
\text { A3: } l i n= & p_{i n} \alpha_{i n}+\left(1-p_{i n}\right) \alpha_{j n}+\beta_{L} \operatorname{cov}_{L} \\
\text { B4: } \operatorname{lin}= & \left(p_{i}+\delta p \times \mathrm{AGE}\right) \alpha_{i n} \\
& +\left[\left(1-p_{i}\right)-\delta p \times \mathrm{AGE}\right] \alpha_{j n}+\beta_{L} \operatorname{cov}_{L}
\end{aligned}
$$

B5: $l i n=\left(p+\delta p_{i} \times \mathrm{AGE}\right) \alpha_{i n}$

$$
+\left[(1-p)-\delta p_{i} \times \mathrm{AGE}\right] \alpha_{j n}+\beta_{L} \operatorname{cov}_{L}
$$

B6: $l i n=\left(p_{i}+\delta p_{i} \times \mathrm{AGE}\right) \alpha_{i n}$

$$
+\left[\left(1-p_{i}\right)-\delta p_{i} \times \mathrm{AGE}\right] \alpha_{j n}+\beta_{L} \operatorname{cov}_{L}
$$

\section{DATA REFERENCES}

Allerbeck, K. R., M. Kaase, H. D. Klingemann, F. J. Heunks, P. C. Stouthard, J. J. A. Thomassen, J. W. von Deth, S. H. Barnes, B. G. Farah, R. Inglehart, and M. K. Jennings. 1980. Political Action II. Distributed by the Zentralarchiv fuer Empirische Sozialforschung, University of Cologne, Cologne, ZA 1188.

Arts, K., E. Hollander, K. Renckstorf, and P. Verschuren. 1989. Grootschalig onderzoek naar media-uitrusting, media-exposure en mediagebruik in Nederland, 1989. Data obtained from the authors.

Barnes, S. H., and M. Kaase. 1976. Political Action: An Eight Nation Study, 19731976. Distributed by the Inter-university Consortium for Political and Social Research, Ann Arbor, Mich. ICPSR 7777.

Butler, D., and D. E. Stokes. 1963-66. Political Change in Britain, 1963-1970: (1) Cross-Section Sample, 1963; (2) Electorate Sample, 1964; (3) Electorate Sample, 1966. Distributed by the Inter-university Consortium for Political and Social Research, Ann Arbor, Mich. ICPSR 7232-7250-7233-7234.

- 1970. Political Change in Britain, 1969-1970. Distributed by the Interuniversity Consortium for Political and Social Research, Ann Arbor, Mich. ICPSR 7004.

CBS (Centraal Bureau voor de Statistiek). 1977. Life (Situation) Survey, Netherlands, 1977. Distributed by the Steinmetz Archive, Amsterdam. P0328.

Crewe, I., B. Saerlvik, and J. Alt. 1974. British Election Study: 1974, October. Distributed by the Inter-university Consortium for Political and Social Research, Ann Arbor, Mich. ICPSR 7870.

Crewe, I., B. Saerlvik, and D. Robertson. 1979. British Election Study: 1979 CrossSection, May. Distributed by the Inter-university Consortium for Political and Social Research, Ann Arbor, Mich. ICPSR 8196.

Davis, J. A., and T. W. Smith. 1991. General Social Survey Cumulative File, 1972 1991. Distributed by the Inter-university Consortium for Political and Social Research, Ann Arbor, Mich. ICPSR 9505.

Eisinga, R., A. Felling, J. Peters, P. Scheepers, and O. Schreuder. 1990. Religion in Dutch Society 90. Distributed by the Steinmetz Archive, Amsterdam. P1100.

Felling, A., J. Peters, and O. Schreuder. 1985. Religion in Dutch Society 85. Distributed by the Steinmetz Archive, Amsterdam. P1012.

Heath, A. F., R. Jowell, J. Curtice, and J. Field. 1983. British Election Study, (June) 
1983. Distributed by the Social Science Research Council. University of Essex, Essex. 2005.

Heath, A. F., R. Jowell, J. Curtice, J. Field, and S. Witherspoon. 1989. British Election Study, 1987. Distributed by the Social Science Research Council. University of Essex, Essex. SN 2568.

Hermkens, P., and P. Van Wijngaarden. 1976. Criteria for Justification of Income Differences, Netherlands, 1976. Distributed by the Steinmetz Archive, Amsterdam. P0653.

Heunks, F. J., M. K. Jennings, W. E. Miller, P. C. Stouthard, and J. Thomassen. 1973. Dutch Election Study, 1970-1973. Distributed by the Inter-university Consortium for Political and Social Research, Ann Arbor, Mich. ICPSR 7261.

International Social Science Program. 1987. Social Inequality, 1987. Distributed by the Inter-university Consortium for Political and Social Research, Ann Arbor, Mich. ICPSR 9383.

Kaase, M., and U. Schleth. 1969. German Election Study: 1969, August-September. Distributed by the Inter-university Consortium for Political and Social Research, Ann Arbor, Mich. ICPSR 7108. Also distributed by the Zentralarchiv fuer Empirische Sozialforschung. University of Cologne, Cologne. ZA 0525.

Klingemann, H. D., and F. U. Pappi. 1969. German Pre- and Post-election Study, 1969. Distributed by the Inter-university Consortium for Political and Social Research, Ann Arbor, Mich. ICPSR 7098.

Van der Eijk, C. B., G. A. Irwin, and B. Niemoeller. 1986. Dutch Parliamentary Election Study, 1986. Distributed by the Steinmetz Archive, Amsterdam. P0866A.

Van der Eijk, C. B., B. Niemoeller, and A. T. J. Eggen. 1981. Dutch Parliamentary Election Study, 1981. Distributed by the Steinmetz Archive, Amsterdam. P0350.

Van der Eijk, C. B., B. Niemoeller, M. J. Koopman, and S. M. J. Koopman. 1982. Dutch Parliamentary Election Study, 1982. Distributed by the Steinmetz Archive, Amsterdam. P0633A.

Verba, S., N. H. Nie, and J. Kim. 1971. Cross-National Program in Political and Social Change: Netherlands Cross-Sectional Survey. Distributed by the Interuniversity Consortium for Political and Social Research, Ann Arbor, Mich. ICPSR 7768.

Werkgroep Nationaal Kiezersonderzoek. 1977. Dutch Parliamentary Election Study, 1977. Distributed by the Steinmetz Archive, Amsterdam. P0354.

ZUMA (Zentrum fuer Umfragen, Methoden, und Analysen). 1980. ZUMA-Standarddemographie (Zeitreihe), Germany, 1976-1980. Distributed by the Zentralarchiv fuer Empirische Sozialforschung, University of Cologne, Cologne. ZA 1233. . 1988. German Social Survey (Allbus) Cumulative File, 1980-1988. Distributed by the Zentralarchiv fuer Empirische Sozialforschung, University of Cologne, Cologne. ZA 1795.

1990. German Social Survey (Allbus), 1990. Distributed by the Zentralarchiv fuer Empirische Sozialforschung, University of Cologne, Cologne. ZA 1800.

\section{REFERENCES}

Abramson, P. R. 1972. "Intergenerational Social Mobility and Partisan Choice." American Political Science Review 66:1291-94.

Barber, J. A., Jr. 1970. Social Mobility and Voting Behavior. Chicago: University of Chicago Press.

Bartolini, S., and P. Mair. 1990. Identity, Competition and Electoral Availability: The Stabilization of European Electorates, 1885-1985. Cambridge: Cambridge University Press. 
Blau, P. M. 1956. "Social Mobility and Interpersonal Relations." American Sociological Review 21:290-95.

. 1964. Exchange and Power in Social Life. New York: Wiley.

Blau, P. M., and J. E. Schwartz. 1984. Crosscutting Social Circles: Testing a Macrostructural Theory of Intergroup Relations. Orlando, Fla.: Academic Press.

Burstein, L., R. L. Linn, and F. J. Capell. 1978. "Analyzing Multilevel Data in the Presence of Heterogeneous Within-Class Regressions." Journal of Educational Statistics 3:347-83.

Clark, T. N., and S. M. Lipset. 1991. "Are Social Classes Dying?" International Sociology 6:397-410.

Clifford, P., and A. Heath. 1993. "The Political Consequences of Social Mobility." Journal of the Royal Statistical Society 156:1-11.

Converse, P. E. 1958. "The Shifting Role of Class in Political Attitudes and Behavior." Pp. 388-99 in Readings in Social Psychology, 3d ed. Edited by E. E. Maccoby, T. M. Newcomb, and E. L. Hartley. New York: Holt.

De Graaf, N. D. 1991. "Distinction by Consumption in Czechoslovakia, Hungary, and the Netherlands." European Sociological Review 7:267-90.

De Graaf, N. D., and H. B. G. Ganzeboom. 1990. "Cultuurdeelname en opleiding: een analyse van status groep-effecten met diagonale referentiemodellen" (Culture consumption and education: An analysis of status-group effects with diagonal reference models). Mens en Maatschappij 65:2-27.

De Graaf, N. D., and A. F. Heath. 1992. "Husbands' and Wives' Voting Behavior in Britain: Class-Dependent Mutual Influence of Spouses." Acta Sociologica 35:311-22.

De Graaf, N. D., and W. Ultee. 1990. "Individual Preferences, Social Mobility and Electoral Outcomes." Electoral Studies 9:109-32.

Downs, A. 1957. An Economic Theory of Democracy. New York: Harper and Row.

Duncan, O. D. 1966. "Methodological Issues in the Analysis of Social Mobility." Pp. 51-97 in Social Structure and Mobility in Economic Development, edited by N. L. Smelser and S. M. Lipset. Chicago: Aldine.

Durkheim, É. 1897. Le Suicide: Étude de sociologie. Paris: Alcan.

Erikson, R., and J. H. Goldthorpe. 1985. "Are American Rates of Social Mobility Exceptionally High? New Evidence on an Old Issue." European Sociological Review 1:1-22.

. 1992. The Constant Flux: A Study of Class Mobility in Industrial Societies. Oxford: Clarendon.

Erikson, R., J. Goldthorpe, and J. Portocarero. 1979. "Intergenerational Class Mobility in Three Western European Societies." British Journal of Sociology 30:415-41.

Franklin, M. N., T. Mackie, and H. Valen, eds. 1992. Electoral Change: Responses to Evolving Social and Attitudinal Structures in Western Countries. Cambridge: Cambridge University Press.

Ganzeboom, H. B. G., R. Luijkx, and D. J. Treiman. 1989. "Intergenerational Class Mobility in Comparative Perspective." Research in Social Stratification and Mobility 8:3-84.

Girod, R. 1971. Mobilité sociale: Faits établis et problèmes ouverts. Geneva: Droz.

Goldstein, H. 1987. Multilevel Models in Educational and Social Research. London: Griffin.

Goldthorpe, J. H. 1980. Social Mobility and Class Structure in Modern Britain. Oxford: Clarendon.

Heath, A. F., R. Jowell, and J. Curtice. 1985. How Britain Votes. Oxford: Pergamon.

Heath, A. F., R. Jowell, J. Curtice, G. Evans, J. Field, and S. Witherspoon. 1991. Understanding Political Change. Oxford: Pergamon.

Heath, A. F., B. Taylor, and G. Toka. 1993. "Religion, Morality and Politics." Pp. 49-80 in International Social Attitudes: The 10th BSA Report, edited by R. Jowell, L. Brook, and L. Dowds. Aldershot: Dartmouth. 
Hendrickx, J., N. D. De Graaf, J. Lammers, and W. Ultee. 1993. "Models for Status Inconsistency and Mobility: A Comparison of the Approaches by Hope and Sobel with the Mainstream Square Additive Model." Quality and Quantity 27:335-52.

ILO (International Labour Office). 1969. International Standard Classification of Occupations, rev. ed., 1968. Geneva: International Labour Office.

Janowitz, M. 1970. Political Conflict. Chicago: Quadrangle.

Kelley, J. 1992. "Social Mobility and Politics in the Anglo-American Democracies." Pp. 21-50 in Social Mobility and Political Attitudes: Comparative Perspectives, edited by F. Turner. New Brunswick, N.J.: Transaction.

Knoke, P. 1973. "Intergenerational Occupational Mobility and the Political Party Preferences of American Men." American Journal of Sociology 78:1448-68.

Lipset, S. M. 1960. Political Man: The Social Bases of Politics. London: Heinemann Educational Books.

Lipset, S. M., and R. Bendix. 1959. Social Mobility in Industrial Society. Berkeley: University of California Press.

Lipset, S. M., P. F. Lazarsfeld, A. H. Barton, and J. Linz. 1954. "The Psychology of Voting: An Analysis of Political Behavior." Pp. 1124-75 in Handbook of Social Psychology, edited by G. Lindzey. Cambridge, Mass.: Addison-Wesley.

Lipset, S. M., and H. Zetterberg. 1956. "A Theory of Social Mobility." Transactions of the Third World Congress of Sociology 3:155-77.

Longford, N. T. 1988. VARCL: Software for Variance Component Analysis of Data with Hierarchically Nested Random Effects. Princeton, N.J.: Educational Testing Service.

Marx, K. 1926. The Eighteenth Brumaire of Louis Bonaparte, translated by P. Eden and P. Cider. London: Allen Unwin.

Nieuwbeerta, P., and N. D. De Graaf. 1993. "Intergenerational Class Mobility and Political Preference in the Netherlands between 1970 and 1986." Netherlands Journal of Social Sciences 29:27-45.

Nieuwbeerta, P. 1995. The Democratic Class Struggle in 20 Countries, 1945-1990. $\mathrm{Ph} . \mathrm{D}$. dissertation. University of Nijmegen. In press.

Parkin, F. 1971. Class, Inequality and Political Order: Social Stratification in Capitalist and Communist Societies. London: Palladin.

Raftery, A. 1986. "Choosing Models for Cross-Classifications: Comment on Grusky and Hauser." American Sociological Review 51:145-46.

Sobel, M. E. 1981. "Diagonal Mobility Models: A Substantively Motivated Class of Designs for the Analysis of Mobility Effects." American Sociological Review 46:893-906.

. 1985. "Social Mobility and Fertility Revisited: Some New Models for the Analysis of the Mobility Effects Hypothesis." American Sociological Review 50:699-712.

Sorokin, P. A. 1957. Social and Cultural Mobility. Glencoe, Ill.: Free Press.

Thorburn, P. 1979. "Class and Mobility: The Political Preferences of Men in England and Wales." Ph.D. dissertation. University of Michigan, Department of Political Science.

Turner, F. 1992. Social Mobility and Political Attitudes: Comparative Perspectives. New Brunswick, N.J.: Transaction.

Ultee, W. C., and N. D. De Graaf. 1991. "Cultuurdeelname en opleidingsverschillen in primaire relaties: De invloed van intergenerationele mobiliteit en gemengde huwelijken" (Cultural consumption in primary relations: The influence of intergenerational mobility and mixed marriages). Gezin 3:244-58.

Weakliem, D. L. 1992. "Does Social Mobility Affect Political Behavior?" European Sociological Review 8:153-65. 